\title{
PENGARUH BIAYA PROMOSI TERHADAP PENJUALAN PRODUK INDOSAT DI BANDAR LAMPUNG
}

\author{
Khairul Saleh ${ }^{(1)}$, Medy Iswara ${ }^{(2)}$ \\ Fakultas Ekonomi Universitas Sang Bumi Ruwa Jurai \\ khairul.saleh@fe.saburai.ac.id,medy_iswaraa@gmail.com
}

\begin{abstract}
Abstrak. Promosi merupakan bagian dari salah satu aspek dari manajemen pemasaran. Karena promosi disini dapat dipandang sebagai arus informasi atau arah yang dibuat umtuk mengarahkan individu atau kelompok kepada tindakan yang menciptakan kegiatan pertukaran atau pemasaran. Indosat Bandar lampung 2015 dalam menetapkan biaya promosi, perusahaan sudah memiliki anggaran promosi yang disesuaikan anggarnya selama satu tahun tetapi nilai terealisasi penjualan tidak sesuai dengan tareget penjualan meskipun biaya promosi cenderung meningkat setiap bulannya. Tujuan penelitian ini adalah untuk mengetahui pengaruh biaya promosi terhadap nilai penjualan pada Indosat Bandar Lampung. Hasil penelitian menunjukkan bahwa biaya promosi berpengaruh secara positif dan signifikan terhadap nilai penjualan Indosat Bandar lampung. Hal ini dibuktikan dengan uji t atau uji parsial variabel biaya promosi sebesar $t_{\text {hitung }}$

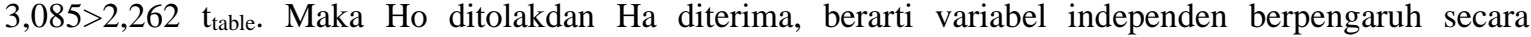
signifikan terhadap variabel depeden. Hal ini menunjukan biaya promosi berpengaruh positif dan signifikan terhadap nilai penjualan pada Indosat Bandar Lampung.
\end{abstract}

Kata kunci: Biaya, Nilai, Produk, Promosi.

\section{PENDAHULUAN}

Pemasaran merupakan salah satu dari kegiatan-kegiatan pokok yang dilakukan oleh para perusahaan dalam usahanya untuk mempertahankan kelangsungan perusahaan, untuk berkembang dan untuk mencapai sesuai target yang diinginkan. Berhasil tidaknya dalam pencapaian tujuan tergantung kepada keahlian perusahaan di bidang pemasaran, produksi, keuangan maupun bidang lain. Selain itu tergantung pula pada kemampuan perusahaan untuk mengkombinasikan fungsi-fungsi tersebut agar perusahaan mencapai target yang diinginkan.Inti dari pemasaran adalah mengidentifikasi dan memenuhi kebutuhan manusia dan sosial.

Pada dasarnya tujuan dalam mendirikan perusahaan adalah mencari keuntungan semaksimal mungkin. Keberhasilan suatu perusahaan dalam mencapai tujuan itu sangat dipengaruhi oleh kemampuan perusahaan dalam memasarkan produknya. Perusahaan dapat menjual produknya dengan harga yang menguntungkan pada tingkat kualitas yang diharapkan, akan mampu mengatasi tantangan dari para pesaing terutama dalam bidang pemasaran.

Oleh karena itu untuk menarik konsumen melakukan pembelian maka perusahaan harus bisa menerapkan suatu promosi yang tepat sesuai dengan kondisi pasar yang dihadapi. Hampir setiap perusahaan mengalami persaingan dan tantangan dalam suatu lingkungan. Untuk menghadapi persaingan ini diperlukan promosi sehingga mampu bersaing dan memperkuat keunggulan agar perusahaan mewujudkan penjualan sesuai target.

Promosi merupakan bagian darisalah satu aspek dari manajemen pemasaran. Karena promosi disini dapat dipandang sebagai arus informasi atau arah yang dibuat untuk mengarahkan individu atau kelompok kepada tindakan yang menciptakan kegiatan pertukaran atau 
pemasaran. Promosi yang dilakukan oleh pihak perusahaan diharapkan mendapatkan respon yang positif atau reaksi atas rangsangan yang ditujukan pada konsumen yang dilirik, sehingga konsumen akan melakukan tindakan atas rangsangan yang diberikan sebagai respon.

Tindakan dalam hal ini dapat dikatakan tindakan yang secara individu atau kelompok untuk membeli atau mendapatkan suatu barang atau jasa service untuk dikonsumsi sebagai akibat dari adanya rangsangan karena tindakan atau rangsangan konsumen ini bersifat positif atau negatif maka dengan tindakan yang diberikan konsumen belum tentu membeli produk yang ditawarkan.

PT. Indosat Lampung merupakan perusahaan yang menjual produk-produk komunikasi.PT. Indosat Lampung adalah sebuah perusahaan yang sudah berjalan bertahun-tahun, penting rasanya untuk memahami perilaku konsumen secara serius dan tepat semua ini didasari karena konsumen mempunyai peran penting dalam memilih tempat membeli kartu perdana, voucher dan lainnya. Biasanya sebelum melakukan pembelian konsumen terlebih dahulu memilih yang sesuai dengan keinginan dan kebutuhan mereka atau sudah pernah menjadi konsumen sebelumnya. Keinginan mereka yang pada umumnya pemiilihan ini biasanya didasari kelengkapan buku-buku dan mengenai harga serta kebutuhan konsumen.

Penjualan produk pada Pt. Indosat Bandar Lampung mengalami perkembangan yang tidak stabil. Nilai penjualan mengalami naik dan turun tiap bulannya. Realisasi penjualan tidak pernah tercapai sesuai target PT. Indosat Lampung. Mengacu pada hal tersebut, maka peneliti melakukan penelitian lebih lanjut dengan judul: "Pengaruh Biaya Promosi terhadap Nilai Penjualan pada PT. Indosat Lampung Bandar Lampung".

\section{KAJIAN TEORI}

\section{Pengertian Pemasaran}

Kegiatan pemasaran dewasa ini mempunyai peran yang sangat penting dalam dunia usaha, hal ini disebabkan karena pemasaran merupakan kegiatan pokok yang harus dilakukan oleh suatu perusahaan dalam menjalankan proses penjualan demi mempertahankan kelangsungan hidup dan perkembangan perusahaan untuk masa yang akan datang. Pemasaran merupakan seni menciptakan dan memuaskan pelanggan secara menguntungkan, pemasaran mengantarkan barang dan jasa yang tepat, dan harga barang yang tepat dan komunikasi serta promosi yang tepat.Pengertian pemasaran telah banyak dikemukakan oleh beberapa ahli dengan berbagai teori dan pendapat yang berbeda-beda sesuai dengan sudut pandang mereka.

Adapun defenisi pemasaran menurut Basu Swastha dan Ibnu Sukotjo adalah sistem keseluruhan dari kegiatan usaha yang ditujukan untuk merencanakan, menentukan harga, mempromosikan dan mendistribusikan barang dan jasa yang dapat memuaskan kebutuhan kepada pembeli yang ada maupun pembeli yang potensial. Dari defenisi ini dapat diberikan gambaran bahwa pemasaran ditinjau sebagai suatu sistem kegiatan usaha dimana variabel-variabel kegiatan seperti merencanakan, menentukan harga, mempromosikan, serta mendistribusikan barang dan jasa adalah saling berhubungan dalam memuaskan kebutuhan.

Berdasarkan definisi-definisi tersebut, dapat disimpulkan bahwa pemasaran merupakan suatu kegiatan manusia untuk memenuhi kebutuhan dan keinginan melalui proses penciptaan, penawaran dan pertukaran (nilai) produk dengan yang lain, dimana dalam pemasaran ini kegiatan bisnis dirancang untuk mendistribusikan barang- 
barang dari produsen kepada konsumen untuk mencapai sasaran serta tujuan organisasi.

\section{Konsep Pemasaran}

Konsep pemasaran menyatakan bahwa pencapaian secara organisasi tergantung pada penentuan kebutuhan dan keinginan pasar serta penyampaian kepuasan yang didambakan itu lebih efektif dan efesien dibandingkan pesaing. Konsep pemasaran dinyatakan dengan cara yang berwarnawarni seperti :

1. Kami mewujudkan keinginan anda

2. Terbang untuk melayani

3. Kami tidak puas sebelum anda puas

4. Dan kami bias melebihi harapan anda

Konsep pemasaran dan konsep penjualan mempunyai pengertian yang berbeda. Konsep penjualan mempunyai perspektif dari dalam keluar. Konsep itu sendiri dimulai dengan pabrik, berfokus pada produk perusahaan yang sudah ada dan melakukan penjualan dan promosi besar-besaran untuk memperoleh penjualan yang mampu mendatangkan laba. Sebaliknya konsep pemasaran mempunyai perspektif dari luar ke dalam.Konsep itu memusatkan perhatian penuh pada penaklukan pelanggan mendapatkan penjualan jangka pendek.

Dengan demikian dapat dikatakan bahwa, konsep pemasaran merupakan proses pendistribusian barang yang dilakukan dari luar ke dalam supaya memperoleh laba dan kepuasan pelanggan. Pelanggan itu sendiri adalah orang yang paling penting dalam perusahaan, pelanggan itu sendiri tidak tergantung pada kita. Kita tergantung pada pelanggan.

\section{Pengertian Promosi}

Sehubungan dengan pentingnya peranan promosi, maka dibawah ini akan diuraikan beberapa pendapat dari beberapa ahli tentang pentingnya promosi. Definisi tentang promosi menurut Kotler dan Armstrong (2004) adalah "Segala aktifitas yang mengkomunikasikan keunggulan produk dan membujuk pelanggan sasaran untuk membelinya. Sedangkan definisi promosi penjualan menurut Swasta (2002) adalah " kegiatan-kegiatan pemasaran selain personal selling, periklanan, dan publisitas, yang mendorong efektivitas pembelian konsumen dan pedagang dengan menggunakan alat-alat seperti peragaan, pameran. Demonstrasi dan sebagainya.

Berdasarkan uraian diatas dapat disimpulkan bahwa promosi adalah suatu kegiatan dibidang pemasaran yang dilakukan oleh perusahaan untuk nmeningkatkan nilai penjualan barang atau jasa, melalui penyebaran informasi dan himbauan kepada para pembeli (konsumen) atau pembeli potensial dan setiap perusahaan yang melakukan promosi harus lebih dahulu menentukan tujuan dari promosi agar dapat tercapai secara efektif.

\section{Strategi Promosi}

Promosi memegang peranan penting dalam menghubungkan jarak antara pemroduksi dengan pengonsumsi. Mengadakan promosi, pemroduksi dapat menyampaikan berbagai informasi kepada pengonsumsi. Melalui pesannya, pemroduksi berusaha meyakinkan bahwa produksian mereka tawarkan dapat memuaskan kebutuhan pengonsumsi. Promosi adalah arus infomasi atau persuasi satu arah yang dibuat untuk mengarahkan seseorang atau tindakan menciptakan pertukaran dalam pemasaran (Swasta dan lrawan, 2008).

Menurut Kotler dan Susanto (2007) Promosi adalah berbagai kegiatan perusahaan untuk mengkomunikasikan produksiannya pada pasar sasarannya. Promotion Mix adalah kombinasi strategi 
yang paling baik dari variabel-variabel periklanan, personal selling, dan alat promosi lain yang semuanya ditujukan untuk mencapai tujuan program penjualan. Cara-cara yang banyak dilakukan adalah :

1. Advertising (periklanan), yaitu bentuk presentasi dan promosi non pribadi tentang ide, barang dan jasa yang dibayar oleh sponsor tertentu.

2. Personal selling, yaitu promosi yang dilakukan oleh individu tenaga penjual, bukan lewat surat dan lainnya.

3. Sales promotion (Promosi penjualan), yaitu kegiatan yang direncanakan untuk menambah dan mengkoordinasi kegiatan penjualan personal dan periklanan.

4. Publisitas, yaitu usaha untuk memacu permintaan secara non personal atau usaha yang dibiayai oleh orang atau organisasi yang memetik manfaat dari publikasi itu.

5. Publik relation (hubungan masyarakat), yaitu kegiatan yang merupakan usaha terencana dari suatu organisasi untuk mempengaruhi sikap atau pendapat golongan terhadap badan usaha tersebut. (Stanton, 2007).

\section{METODE PENELITIAN}

\section{Objek Penelitian}

Objek penelitian ini adalah PT. Indosat Lampung di jalan Wolter Monginsidi No. 100 Bandar Lampung. Penelitian ini di laksanakan daribulan April sampai dengan Mei 2016.

\section{Metode dan Teknik Pengumpulan Data}

Penggolongan jenis penelitian sangat tergantung pada peristiwa darimana seseorang hendak meninjau penelitian. Pada penelitian ini menggunakan jenis penelitian:

- Penelitian Kepustakaan (Library Research), penelitian yang dilakukan untuk mengumpulkan data dan informasi dengan bahan-bahan kepustakaan seperti buku literarur.

- Penelitian Lapangan (Field Research), penelitian yang dilakukan dalam kancah kehidupan yang sebenarnya dengan terjun langsung ke obyek penelitian untuk menentukan secara spesifik dan realistis tentang sesuatu yang sedang terjadi.

Teknik pengumpulan data yang digunakan dalam penelitian ini, adalah:

1. Obvservasi

Peneliti melakukan pengamatan langsung ke objek penelitian Toko Buku Gramedia Raden Intan Bandar Lampung.

2. Interview

Yaitu mendapatkan data dengan melakukan tanya jawab yang berguna untuk melengkapi data yang diperoleh dengan metode sebelumnya.

\section{Sampel dan Populasi}

Pengambilan sampel dilakukan dengan pertimbangan bahwa populasi yang ada sangat besar jumlahnya, sehingga tidak memungkinkan untuk meneliti seluruh populasi yang ada, sehingga dibentuk sebuah perwakilan populasi. Sampel dalam penelitian ini yaitu dilakukan pada PT. Indosat Lampung itu sendiri, yaitu laporan penjualan dan beban promosi bulan Januari sampai bulan Desember.

\section{Metode Analisis Data}

Metode analisis data yang digunakan dalam penelitian ini adalah metode analisis 
kuantitatif dengan rumus Regresi Linier Sederhana :

$$
Y=a+b X+e
$$

Keterangan:

$$
\begin{aligned}
\mathrm{Y} & =\text { Nilai penjualan } \\
\mathrm{a} & =\text { Konstanta } \\
\mathrm{b} & =\text { Koefisien regresi } \mathrm{X} \\
\mathrm{X} & =\text { Biaya promosi } \\
\mathrm{e} & =\text { Faktor kesalahan }
\end{aligned}
$$

Untuk mengetahui besarnya pengaruh, penghitungan koefisien korelasi tersebut kemudian dilanjutkan dengan Rumus Koefisien Determinasi atau Koefisien Penentu (KP):

$$
K P=(r)^{2} x 100 \%
$$

Untuk menguji secara hipotesis secara parsial digunakan Uji t dengan rumus :

$$
t_{\text {hitung }}=\frac{r \sqrt{N-2}}{\sqrt{1-r^{2}}}
$$

Keterangan:

$$
\begin{array}{ll}
\mathrm{t}_{\text {hitung }} & =\text { Nilai } \mathrm{t} \\
\mathrm{r} & =\text { Koefisien Korelasi } \\
\mathrm{N} & =\text { Jumlah responden }
\end{array}
$$

Kriteria untuk Uji $\mathrm{t}$ adalah sebagai berikut :

a. Apabila nilai $t_{\text {hitung }}<\mathrm{t}_{\text {tabel }}$ atau $\rho<0,05$, maka Ho diterima dan Ha yang berarti variabel independen tidak berpengaruh secara signifikan terhadap variabel dependen.

b. Apabila nilai thitung $>t_{\text {tabel }}$ atau $\rho>0,05$ maka Ho ditolak dan Ha diterima yang berarti variabel independen berpengaruh secara signifikan terhadap variabel dependen.

\section{HASIL DAN PEMBAHASAN}

Berdasarkan hasil pengujian dengan menggunakan rumus regresi linier sederhana, maka berikut hasil analisis data yang dilakukan untuk meneliti Pengaruh Biaya Promosi Terhadap Nilai Penjualan Pada Indosat Bandar Lampung Selama 1 Tahun yaitu tahun 2015 .

\section{Uji Validitas}

Uji validitas digunakan untuk menguji sejauh mana ketepatan alat pengukur dapat mengungkapkan konsep gejala/kejadian yang diukur. Pengujian validitas dilakukan dengan menggunakan rumus korelasi.

\section{Uji Reliabilitas Data}

Pengujian reliabilitas dalam penelitian ini adalah dengan menggunakan rumus Alpha. Hasil uji reliabilitas pada Tabel 2. Menunjukkan semua konsep pengukur masing-masing variabel dari kuesioner adalah reliabel sehingga untuk selanjutnya item-item pada masing-masing konsep variabel sebagai alat ukur.

\section{Analisis Kuantitatif}

Koefisien determinasi ( $\left.\mathrm{R}^{2}\right)$ pada intinya digunakan untuk mengukur seberapa jauh kemampuan model regresi dalam menerangkan variabel-variabel dependen (Ghozali, 2006). Nilai koefisien determinasi $\left(\mathrm{R}^{2}\right)$ variabel Biaya Promosi terhadap Nilai Penjualan sebesar 0,488. Hal ini menunjukkan bahwa pengaruh koefisien variabel Biaya Promosi terhadap Nilai Penjualan sebesar $48,8 \%$, sisanya sebesar 41,2\% dipengaruhi oleh faktor lain diluar penelitian. Hal ini berarti setiap tambahan satu variabel Biaya Promosi , maka $\mathrm{R}^{2}$ pasti meningkat tidak peduli apakah variabel tersebut berpengaruh secara signifikan terhadap variabel Nilai Penjualan. 
Hasil uji regresi sederhana adalah $\mathrm{Y}=$ 293.112.619,44+ 2,561X+e. Dari hasil uji regresi sederhana di preloeh nilai promosi ( $\mathrm{X}$ ) jika naik 1 persen ( $1 \%$ ) maka nilai $\mathrm{X}$ penjualan akan naik sebesar 2,561.

Hasil nilai $\mathrm{t}$ variabel biaya promosi sebesar $t_{\text {hitung }} 3,085>2,228 t_{\text {tabel }}$. Maka Ho ditolak dan $\mathrm{Ha}$ diterima, berarti variabel independen biaya promosi berpengaruh secara signifikan terhadap variabel dependen nilai penjualan. Hal ini menunjukkan Biaya Promosi berpengaruh positif dan signifikan terhadap Nilai Penjualan pada Indosat Bandar Lampung.

Berdasarkan hasil pengujian menggunakan metode regresi linier sederhana menunjukkan Biaya Promosi berpengaruh secara positif dan signifikan terhadap Nilai penjualan Indosat Bandar Lampung. Hal ini dibuktikan dengan uji $\mathrm{t}$ atau uji parsial variabel biaya promosi sebesar $t_{\text {hitung }} 3,085>2,228 \mathrm{t}_{\text {tabel}}$, berarti variabel independen berpengaruh secara signifikan terhadap variabel dependen. Hal ini menunjukkan Biaya Promosi berpengaruh positif dan signifikan terhadap Nilai Penjualan pada Indosat Bandar Lampung.

Hal ini sesuai dengan teori menurut Tjiptono (1999), promosi adalah bentuk komunikasi pemasaran. Promosi adalah suatu kegiatan dibidang pemasaran yang dilakukan oleh perusahaan untuk nmeningkatkan nilai penjualan barang atau jasa, melalui penyebaran informasi dan himbauan kepada para pembeli (konsumen) atau pembeli potensial dan setiap perusahaan melakukan promosi harus lebih dahulu menentukan tujuan dari promosi agar dapat tercapai secara efektif.

\section{KESIMPULAN DAN SARAN}

\section{Kesimpulan}

Berdasarkan hasil penelitian dan pembahasan yang sudah dilakukan, maka hal yang dapat disimpulkan bahwa biaya promosi berpengaruh secara positif dan signifikan terhadap nilai penjualan Indosat Bandar Lampung. Hal ini dibuktikan dengan uji t atau uji parsial variabel biaya promosi sebesar $\mathrm{t}$ hitung 3,085>2,262 $\mathrm{t}$ tabel. Maka Ho ditolak dan Ha diterima, berarti variabel independen berpengaruh secara signifikan terhadap variabel dependen. Hal ini menunjukkan Biaya Promosi berpengaruh positif dan signifikan terhadap Nilai Penjualan pada Indosat Bandar Lampung.

\section{Saran}

Berdasarkan hasil simpulan penelitian yang telah dijelaskan, maka beberapa hal yang bisa menjadi masukan bagi PT. Indosat antara lain:

1. Sebaiknya PT. Indosat lebih meningkatkan biaya promosi untuk meningkatkan nilai penjualan sehingga mampu mencapai target penjualan yang telah ditentukan. dari hasil penelitian menujukkan bahwa Biaya Promosi berpengaruh secara positif dan signifikan terhadap nilai penjualan. Hal ini berarti kegiatan promosi yang dilakukan oleh PT Indosat sebenarnya sudah baik, hanya saja melihat pencapaian target yang masih belum tercapai, berarti promosi yang dilakukan belum efektif.

2. Sebaiknya PT Indosat melakukan peningkatan Biaya Promosi dengan menambahkan bauran promosi sehingga dapat meningkatkan efektifitas dari promosi penjualan. Beberapa hal yang bisa dilakukan PT Indosat berkeitan dengan meningkatkan Nilai penjualan tersebut antara lain dengan: Periklanan ( Advertising ), Promosi Penjualan ( Sales Promotion), Acara dan Pengalaman ( Event \& Experiece ), Hubungan Masyarakat atau Publisitas ( Public Relation ), Pemasaran Langsung ( Direct 
Marketing ), Pemasaran Interaktif ( Interactive Marketing ), Pemasaran dari Mulut ke Mulut ( Mouth of Mouth), Penjualan Personal ( Personal Selling ).

\section{DAFTAR PUSTAKA}

Basu, Swastha dan Ibnu Sukotjo. 2002. Manajemen Pemasaran Modern. Yogyakarta: Liberty.

Basu, Swastha dan Irawan. 2008. Manajemen Pemasaran Modern. Yogyakarta: Liberty.

Harnanto. 2008. Akuntansi Keuangan Intermediete. Yogyakarta: Liberty.

Iswara, Medy. 2016. Pengaruh Biaya Promosi Terhadap Penjualan Produk Indosat Di Bandar Lampung. Skripsi. Fakultas Ekonomi Program Studi Manajemen Universitas Bandar Lampung.

Kotler, Philip dan Garry Amstrong. 1997. Prinsip-prinsip Pemasaran Edisi Ketiga. Jakarta: Erlangga.

Kotler, Philip dan Amstrong. 2004. PrinsipPrinsip Pemasaran. Alih Bahasa Oleh Wisnu Chandra Kristiaji Jilid 2 Edisi Ke 8. Jakarta: Erlangga.

Kotler, Philip. 2005. Manajemen Pemasaran Jilid 1. Klaten: PT. Intan Sejati.

Kotler, Philip dan Susanto. 2008. Manajemen Pemasaran Di Indonesia. Jakarta: Salemba Empat.

Machfoedz. 2000. Akuntansi Manajemen. Yogyakarta: BPFE.

R Don, Hansen dan Maryanne M. Mowen. 2000. Akuntansi Manajemen, Edisi Ke Dua,terjemahan. Jakarta: Erlangga.
Simamora, Henry. 2002. Manajemen Pemasaran Internasional. Surabaya: Pustaka Utama.

Stanton. 2002. Prinsip-Prinsip Pemasaran. Jakarta: Erlangga.

Tjiptono. 1999. Strategi Pemasaran. Yogyakarta: Liberty. 